\title{
Combination Therapy with Interleukin-2 and Wild-Type p53 Expressed by Adenoviral Vectors Potentiates Tumor Regression in a Murine Model of Breast Cancer
}

\author{
B.M. PÜTZER, ${ }^{1}$ J.L. BRAMSON, ${ }^{1,2}$ C.L. ADDISON, ${ }^{1}$ M. HITT, ${ }^{1}$ P.M. SIEGEL, ${ }^{2}$ W.J. MULLER, ${ }^{2}$ \\ and F.L. GRAHAM ${ }^{1,2}$
}

\begin{abstract}
Although cytokine gene transfer for cancer treatment can stimulate immune recognition and tumor regression in animal models, there is still a need for improvements to these strategies. In this study, we examined the efficacy of a combination gene therapy using adenovirus (Ad) 5 vectors expressing human interleukin-2 and the wild-type (wt) human p53 gene under control of the human cytomegalovirus immediate early promoter (AdIL-2 and Adp53wt, respectively). Infected murine cell lines and primary mouse tumor cells secreted high levels of IL-2 and over expressed the p53 protein for at least 9 days. After infection of cells with Adp53wt, DNA synthesis was significantly inhibited and apoptosis was induced within 3-5 days. Both vectors were tested in a transgenic mouse mammary adenocarcinoma model for antitumor response. Following a single intratumoral injection of mice bearing PyMT induced tumors, the combination of Adp53wt $\left(1 \times 10^{9} \mathrm{pfu}\right)$ plus a relatively low dose of AdIL-2 $\left(1.5 \times 10^{8} \mathrm{pfu}\right)$ caused regressions in $65 \%$ of the treated tumors without toxicity. Fifty percent of the treated mice remained tumor free and were immune to rechallenge with fresh tumor cells. In contrast, injection of either vector alone at this does resulted in only a delay in tumor growth. Only mice co-injected with Adp53wt and AdIL-2 showed specific antitumor cytolytic T lymphocyte (CTL) activity, indicating that the immune response involved in tumor regression was promoted by the combination therapy. These results suggest that cancer treatment strategies involving combined delivery of immunomodulatory and antiproliferative genes may be highly effective.
\end{abstract}

\section{OVERVIEW SUMMARY}

Gene transfer of combinations of genes expressing immunomodulatory functions and suppressors of tumor growth could be the basis for new strategies to potentiate tumor regression in vivo. We examined the efficacy of combined treatment with Ad-vectors expressing IL-2, an immune activator, and p53, a tumor suppressor, in a transgenic murine breast model. Both genes were efficiently expressed in murine cells, and Adp53wt-infected cells showed significant inhibition of cell growth and underwent apoptosis. Combining Adp53wt with AdIL-2 allowed the dosage of the latter to be decreased, eliminating IL-2 related toxicity while retaining ability to induce complete tumor regression.

\section{INTRODUCTION}

LTHOUGH Most TUMORs, including those of the breast, are
1971; Grosser and Thomson, 1975; Parmiani et al., 1997), tu-
mors acquire mechanisms to evade their elimination by cyto-
toxic T cell responses (Howard, 1983; Ludwig et al., 1985).
Therefore, one important strategy for cancer treatment is stim-
ulation of specific antitumor immunity. Many groups, includ-
ing ours, have demonstrated that cytokine gene transfer stimu-
lates antitumor host immune activity resulting in tumor rejection
(for review, see Addison et al., 1995; Bramson et al., 1996b;
Lotze, 1996; Bubenik, 1997; Parmiani et al., 1997; Pützer et
al., 1997).
In a previous study, we treated tumor-bearing mice by in-

Departments of ${ }^{1}$ Biology and ${ }^{2}$ Pathology, McMaster University, Hamilton, Ontario L8S4K1, Canada. 
tratumoral injection with an adenoviral (Ad) vector expressing interleukin-2 (IL-2) and achieved regression of established mammary adenocarcinomas and long-term protective immunity (Addison et al., 1995). Our results and a series of other reports using IL-2-transduced tumor cells (Clary et al., 1997), fibroblasts (Cao et al., 1995), or tumor-infiltrating lymphocytes (TILs; Tan et al., 1996) to enhance immune functions and antitumor activity provide preclinical evidence for the utility of IL-2 expression in gene therapy. The antitumor effect of IL- 2 has been shown to be primarily based on a cytotoxic $\mathrm{T}$ cell-mediated killing activity (Fearon et al., 1990; Gansbacher et al., 1990), and macrophages, granulocytes, lymphokine-activated killer cells (LAK), and TILs were identified as major components of the primary tumor infiltrate (Bannerji et al., 1994). Unfortunately, in addition to the therapeutic benefit, in vivo treatment by Ad-vectors expressing $\mathrm{IL}-2$ at doses needed to induce regression is associated with IL-2-dependent toxicity, resulting in death of a significant fraction of injected animals (Addison $e t$ al., in preparation; Huang et al., 1996; Toloza et al., 1996). These studies define the potential but also indicate the limitations of immunotherapy using $\mathbb{L}-2$ and likely other cytokines. To develop therapeutic approaches that may circumvent or alleviate this problem, we are investigating the use of immunomodulatory genes in combination with an alternate genetic target able to limit tumor growth to permit the use of lower amounts of AdIL-2 and reduced IL-2 toxicity. Previous protocols using combinations of $I L-2$ and the herpes simplex virus thymidine kinase or interferon- $\beta$ (Chen et al., 1995; Sun et al., 1995), and recently, combination of cyclin kinase inhibitors together with allogeneic MHC class I genes (Ohno et al., 1997) or p53 (Sandig et al., 1997), respectively, provide support for the use of combination therapies to produce tumor regression and immunity more efficiently than by either treatment alone.

Interesting candidates for genes to be used in combination with cytokines are those encoding antiproliferative proteins. Several reports (predominantly using Ad vectors) have demonstrated the ability of the wild-type 533 gene product to suppress cancer cell growth both in vitro and in vivo in a variety of different tumor models (Cirielli et al., 1995; Clayman et al., 1995; Hamada et al., 1996; Spitz et al., 1996; Asgari et al., 1997; Hsiao et al., 1997; Xu et al., 1997). Wild-type p53 over-expression by Ad vectors has been shown to inhibit tumor growth in vivo over at least 21 days after injection (Cirielli et al., 1995; Hamada et al., 1996) with a $60-80 \%$ reduction in tumor size (Spitz et al., 1996) and in some cases induction of complete regression (Hamada et al., 1996; Asgari et al., 1997). Moreover, Roth and colleagues (Roth et al., 1996) recently described tumor regression in two patients with non-small cell lung cancer by direct injection of retrovirally expressed wild-type p53. Over-expression of the wild-type protein has been demonstrated to induce a reversible cell cycle arrest at the $G_{1} / S$ transition point (Lin et al., 1992), directly implicating p53 in negative regulation of cell proliferation. Additionally important mechanisms by which p53wt could produce clinical benefit include the induction of apoptosis (Cirielli et al., 1995; Liu et al., 1995; Yang et al., 1995; Gomez-Manzano et al., 1996) by a pathway distinct from the mechanism leading to cell growth arrest. Recent results suggest initiation of growth arrest or killing of nontransduced tumor cells may be mediated by transduced cells through a so called bystander effect (Roth et al., 1996; Asgari et al., 1997; Xu et al., 1997), possibly due to p53 induced an- tiangiogenic proteins (Dameron et al., 1994; Xu et al., 1997). Considering the short half-life of wt p53 and the relatively low transduction efficiency of some gene transfer systems (Roth $e t$ al., 1996; Xu et al., 1997), bystander effects must be invoked to explain sustained tumor cell growth inhibition. Although the great majority of the present studies are based on reconstituting the normal p53 function in tumor cells with defective p53, current studies indicate that the endogenous p53 status may have little impact on the effectiveness of exogenous wild-type p53 protein. p53 over-expressed by viral vectors (Clayman et al., 1995; Liu et al., 1995) or transferred in liposomes (Hsiao et al., 1997) exhibits both growth inhibition and programmed cell death in culture and in tumors regardless of whether the tumor cells express wild-type or mutated p53. Important for in vivo p53 therapy is that none of these studies reported evidence for treatment related toxicity.

Previously, we showed that over-expression of the human wild-type p53 protein in SK-OV-3 cells by adenovirus-mediated gene transfer suppresses cell growth in vitro (Bacchetti and Graham, 1993). In the present study, we examined in vivo effects following intratumoral injection of murine breast tumors with Adp53wt, and investigated whether combination therapy with AdIL-2 and Adp53wt can retain the ability to induce tumor regression at nontoxic cytokine doses.

\section{MATERIALS AND METHODS}

\section{Cell culture}

All viruses were grown in 293 cells (Ad5 E1-transformed human embryonic kidney cells; Graham et al., 1997) maintained in monolayer in modified Eagle's medium (MEM) F-11 supplemented with $10 \%$ fetal bovine serum (FBS), except for cesium chloride-banded virus, which was grown in 293 N3S suspension cells in Joklik's modified medium with $10 \%$ heat inactivated horse serum. MRC5 cells (human fibroblasts; ATCC CCL 171), A549 cells (human lung carcinoma; ATCC CCL 185), and the p53-negative (Johnson et al., 1991) human ovarian adenocarcinoma cells line, SK-OV-3 (obtained from $\mathrm{Hal}$ W. Hirte, McMaster University) were grown in $\beta$-MEM plus $10 \%$ FBS. MT1A2 cells (Addison et al., 1997) were derived from a mammary adenocarcinoma isolated from a transgenic mouse carrying the polyoma middle $\mathrm{T}$ (PyMT) gene under the control of the murine mammary tumor virus long terminal repeat (MMTV LTR) (Guy et al., 1992). MT1A2, and primary FVBMT cells prepared by explanting tumor tissue from PyMT transgenic mice, were grown in MEM F-11 medium with $10 \%$ FBS. The NDL8142 cell line was derived from a mammary carcinoma isolated from a transgenic mouse expressing a (MMTV)/neu fusion gene (M. Hitt, P.M. Siegel, and W.J. Muller; unpublished) consisting of an in-frame deletion in the extracellular domain of Neu proximal to the transmembrane domain corresponding to Neu8142 (Siegel et al., 1994; Siegel and Muller, 1996). NDL8142 cells and p53 mutant (Hamada et al., 1996) C33A cells (human cervical cancer; kindly provided by Peter Whyte, McMaster University) were grown in Dulbecco's medium plus $10 \%$ FBS. Media were supplemented with $2 \mathrm{mM}$ $\mathrm{L}$-glutamine, $100 \mu \mathrm{g} / \mathrm{ml}$ penicillin, and $100 \mathrm{U} / \mathrm{ml}$ streptomycin. Culture media and supplements were obtained from GIBCOBRL. 


\section{Recombinant adenoviruses}

Construction of Ad vectors expressing human wild-type (wt) or mutated (m) p53 protein, Adp53wt and Adp53m, has been described previously (Bacchetti and Graham, 1993). The mutant p53 gene differs from wild-type by having two point mutations, a Cys-135 to serine mutation, affecting protein functions, and a functionally silent Pro-72 to arginine mutation that alters protein conformation and electrophoretic mobility (Buchman et al., 1988). The AdCAIL-2 vector (referred to here as AdIL-2), encoding the human (h) IL-2 protein has been described previously (Addison et al., 1995). In all three vectors early region 1 (E1) was replaced by an expression cassette consisting of the foreign gene cDNA driven by the human cytomegalovirus immediate early gene (HCMV IE) promoter and terminated by the SV40 large T antigen polyadenylation signal. The control adenovirus, $d l 70-3$, is a mutant of Ad5 deleted in E1 and having a deletion/substitution in E3 (Bett et al., 1994). Ad vectors were constructed, propagated, and titered by standard methods (Graham and Prevec, 1991; Bett et al., 1994; Hitt et al., 1994).

\section{Western blot analysis}

Cells were infected with Adp53wt at a multiplicity of infection (moi) of 100 plaque-forming units (pfu) per cell. At various times after infection, cell monolayers were rinsed with phosphate-buffered saline (PBS) and total cell lysates were prepared by incubating cells in RIPA buffer $(50 \mathrm{mM}$ Tris, $150 \mathrm{mM}$ $\mathrm{NaCl}, 0.1 \% \mathrm{SDS}, 1 \%$ sodium deoxycholate, and $1 \%$ Triton $\mathrm{X}$ $100 \mathrm{pH} 7.2$ ) for $30 \mathrm{~min}$ at $4^{\circ} \mathrm{C}$. Mock- or Addl70-3-infected cells served as controls. Proteins $(5 \mu \mathrm{g} / \mathrm{sample}$, assessed by BCA protein assay; Pierce Chemical Co., Rockford, IL) in SDSloading buffer ( $62.5 \mathrm{mM}$ Tris $\mathrm{pH} 6.8,2 \%$ SDS, $10 \%$ glycerol) were subjected to $12 \%$ SDS-polyacrylamide gel electrophoresis (PAGE) and transferred by electroblot to Immobilon-P nylon membranes (Millipore, Mississauga). The membrane was blocked with 5\% dry milk and $0.1 \%$ Tween 20 (Sigma) in PBS and probed with mouse anti-human p53 monoclonal antibody OP43 (Oncogene). The filters were washed and then probed with horseradish peroxidase-conjugated sheep anti-mouse antibody (Amersham). The membranes were developed according to the Amersham ECL protocol. Relative quantities of p53 protein were determined using a densitometer (Molecular Dynamics Inc., Sunnyvale, CA).

\section{Metabolic labeling and immunoprecipitation}

For detection of endogenous p53, 60-mm dishes of MT1A2, NDL8142, SK-VO-3, and C33A cells were incubated for $48 \mathrm{hr}$, at which time the culture medium was removed and replaced with methionine-free medium. After $30 \mathrm{~min}$ of incubation, 50 $\mu \mathrm{Ci}{ }^{35} \mathrm{~S}$-labeled methionine and cysteine were added $\left({ }^{35} \mathrm{~S}-\right.$ Translabel, ICN Radiochemicals) and cells were incubated at $37^{\circ} \mathrm{C}$ for $1 \mathrm{hr}$. Cells were lysed in RIPA buffer and subjected to immunoprecipitation. A $250-\mu \mathrm{l}$ amount of labeled extract was mixed with an aliquot of $100 \mu \mathrm{l}$ Protein A-Sepharose $(0.07$ $\mathrm{g} / \mathrm{ml}$; Pharmacia) and $10 \mu \mathrm{l}$ of the antibody and incubated for $4 \mathrm{hr}$ at $4^{\circ} \mathrm{C}$. The monoclonal anti-p53 antibodies used were PAb1620, specific for wild-type human and mouse p53 and PAb240, with p53 mutant selective reactivity in immunoprecipitation (Oncogene). Immunoprecipitates were removed by centrifugation and pellets were washed five times with RIPA buffer, and resuspended in SDS-loading buffer, and proteins were subjected to $10 \%$ SDS-PAGE. Gels were dried and exposed to X-ray film (XAR-5, Kodak). The relative molecular weights of the precipitated proteins were determined by including radiolabeled protein markers (Amersham).

\section{Cell growth rate determination}

Cells were seeded in $60-\mathrm{mm}$ dishes at a density of $5 \times 10^{4}$ cells/dish for $24 \mathrm{hr}$ before viral infection. The cells were infected with either Adp53wt or Adp53m at a moi of 100. Culture medium was used for mock infection. Triplicate dishes of each treatment were counted at daily intervals over 5 days after infection. Cell viability was determined by trypan blue exclusion.

\section{$\left[{ }^{3}\right.$ H]Thymidine incorporation assay}

Cells were infected near confluence with either Adp53wt, Adp53m, or the control virus Addl $70-3$ at various moi ranging from 5 to $100 \mathrm{pfu} / \mathrm{cell}$. Infected cells were subcultured and reseeded 4 days after infection at $5 \times 10^{4}$ cells $/ 60-\mathrm{mm}$ plate. Rates of DNA synthesis were measured $24 \mathrm{hr}$ later. Growth medium was removed from the cultures and replaced with $2 \mathrm{ml}$ of fresh medium containing $10 \mu \mathrm{Ci}$ of $\left[{ }^{3} \mathrm{H}\right]$ thymidine (sp. act., $6.7 \mathrm{Ci} / \mathrm{mmol}$; Amersham) and the cells were incubated for a further $30-60 \mathrm{~min}$ at $37^{\circ} \mathrm{C}$. At the end of the labeling period, the monolayers were rinsed with cold PBS and incubated for $1-2 \mathrm{hr}$ at $37^{\circ} \mathrm{C}$ in $10 \mathrm{mM}$ Tris $\mathrm{pH} 7.8$ containing $0.8 \%$ SDS and $500 \mu \mathrm{g} / \mathrm{ml}$ Pronase. Following addition of $10 \%$ cold trichloroacetic acid, the lysates were filtered through glass fiber filters, and the filters were then dried and processed for liquid scintillation counting. The results are presented as averages from duplicate cultures.

\section{DNA fragmentation assay}

Sixty-millimeter dishes of cells were infected with virus at a total moi of 100 using Adp53wt at a moi of 90 and AdIL-2 at a moi of 10 , or the control virus Addl70-3. For low-molecular-weight DNA extraction, mock- or virus-infected cells were harvested at days 1,3 , or 5 post infection and lysed in $50 \mathrm{mM}$ Tris $\mathrm{pH} 7.8,10 \mathrm{~m} M$ EDTA, $1 \% \mathrm{SDS}$, and $0.5 \mathrm{mg} / \mathrm{ml}$ proteinase K. After overnight incubation at $37^{\circ} \mathrm{C}$, cell lysates were digested with $5 \mu \mathrm{g} / \mathrm{ml} \mathrm{RNase}$ A for $3 \mathrm{hr}$ at $37^{\circ} \mathrm{C}$, extracted twice with phenol/chloroform/isoamyl alcohol and DNA was precipitated in sodium acetate/ethanol overnight. Samples were then centrifuged at $15,000 \times g$ for $15 \mathrm{~min}$, resuspended in $10 \mathrm{mM}$ Tris, $1 \mathrm{mM} \mathrm{Na} \mathrm{N}_{2}$ EDTA pH 7.5, and analyzed by electrophoresis in $1.5 \%$ agarose gels in $90 \mathrm{~m} M$ Tris, $90 \mathrm{~m} M$ boric acid, $4 \mathrm{mM}$ EDTA (TBE buffer), and ethidium bromide. In all cases, DNAs extracted from equal numbers of cells were analyzed.

\section{IL-2 expression assay}

Cell monolayers were infected with AdIL-2 at a moi of 10 , medium was changed every day, and, at various times post infection, infected cell supernatants were removed and stored at $-70^{\circ} \mathrm{C}$. Levels of secreted hIL-2 in the medium were quantitated by enzyme-linked immunosorbent assay (ELISA) using the human IL-2 ELISA kit from R \& D Systems, according to the manufacturer's protocol. 
Intratumoral injection with Ad vectors and rechallenge of tumor-free animals

The transgenic PyMT model (Guy et al., 1992) and tumor establishment in syngeneic $\mathrm{FVB} / \mathrm{n}$ mice have been described previously (Addison et al., 1995). Briefly, mammary tumor tissue was explanted from transgenic mice carrying the PyMT cDNA under control of the mouse mammary tumor virus long terminal repeat. After 2-3 days of culture in vitro, the monolayers were trypsinized, washed, and injected subcutaneously into the hind flanks of normal FVB/n mice at a dose of $10^{6}$ cells per animal. The second mammary carcinoma tumor model used in this study is based on the transgenic strain NDL1-2 that harbors the neu proto-oncogene carrying a deletion in the extracellular domain of Neu under the control of the mouse mammary tumor virus (MMTV) promoter/enhancer (P.M. Siegel and W.M. Muller, published; Muller et al., 1988). Syngeneic FVB/n mice subcutaneously injected into the hind flank with $2 \times 10^{6}$ tumor cells of a cell line (NDL8142) derived from the transgenic strain develop rapidly growing tumors within 3 weeks. Mice with visible tumors (in both models approximately 21 days post injection with tumor cells) were injected intratumorally with the appropriate concentration of virus in PBS. Tumors were measured prior to virus injection and subsequently at twice-weekly intervals using calipers, and the tumor volume was calculated from the longest diameter and average width, assuming a prolate spheroid (Addison et al., 1995). Animals were sacrificed when the longest diameter was greater than 15 $\mathrm{mm}$ or when any two measurements were greater than $10 \mathrm{~mm}$. Two to three months after complete regression of primary tumors, the PyMidT mice were rechallenged with freshly isolated tumor cells by subcutaneous injection of $10^{6}$ cells in the opposite flank.

\section{CTL assays}

Spleens were removed from mice 14 days following intratumoral injection of Ad vectors and were minced through metal mesh screens in PBS plus 1\% FBS. Red blood cells were lysed by incubation in $0.83 \% \mathrm{NH}_{4} \mathrm{Cl}$ for $5 \mathrm{~min}$ on ice, washed, and resuspended in PBS plus serum, and lymphocytes were set up in a co-culture with irradiated PyMT expressing 516MT3 cells (Addison et al., unpublished) in a ratio of 100:1 for a period of 5 days in RPMMI-1640 medium with $20 \mathrm{~m} M$ HEPES, $100 \mu M$ $\beta$-mercaptoethanol, and $10 \%$ FBS. Stimulated spleen cells were incubated for $6 \mathrm{hr}$ with ${ }^{51} \mathrm{Cr}$-labeled 516MT3 cells or nonspecific control PT0516 target cells (negative for middle T antigen expression; $100 \mu \mathrm{Ci} / 10^{6}$ cells) at ratios of 90:1, 30:1, 10:1, and 3.3:1 (effector:target) in V-bottomed microtiter plates (NUNC) at $37^{\circ} \mathrm{C}$. Supernatants were removed, and released ${ }^{51} \mathrm{Cr}$ was counted in a gamma counter. The specific release was calculated as described in Bramson et al. (1996a).

\section{RESULTS}

p53 gene status and expression in Adp53wt-infected cells

We examined the endogenous p53 status in primary FVBMT and NDL8142 mammary adenocarcinoma cells by immunoprecipitation using the monoclonal antibodies PAb1620 (specific for wild-type p53 protein) and PAb240 with specificity for mutant p53 (Fig. 1). The p53-negative SK-OV-3 cells (Johnson et al., 1991) and p53 mutant C33A cells (codon 273; Hamada et al., 1996) were used as controls. In both murine breast cancer cells, p53 protein was clearly detected with the PAb1620 antibody but not with the mutant specific antibody. No protein could be detected in p53-negative SK-OV-3 cells. In C33A cells carrying a p53 mutation, protein was only detected by the PAb240 mutant specific antibody, confirming that the wild-type antibody does not cross-react with mutant protein. A lower p53 expression level or greater protein instability might be the reason for the weaker band detected with the Pab240 antibody in C33A cells.

To determine the level and kinetics of p53 expression of Adp53wt, we infected human and murine cell lines and primary mouse tumor cells at a moi of 100 . Cellular protein was extracted at indicated times after infection and analyzed by western blot using the monoclonal antibody OP43 specific for human p53 (shown in Fig. 2A for MT1A2 and NDL8142 cells). The relative expression levels in absorbance units (AU) of murine and human cells analyzed by densitometer are shown in Fig. 2B. The p53 protein was clearly detected after $24 \mathrm{hr}$, regardless of whether human or mouse cells were infected (Fig. 2A,B), and peaked at day 3 in human A549 and MRC5, in agreement with results reported by Hamada et al. (1996), and between days 3 (MT1A2) and 5 (FVBMT, NDL8142) in mouse cells (Fig. 2B). In primary FVBMT cells derived from tumors of PyMT transgenic mice, and NDL8142 cells, expression on the ninth day after infection had declined by less than 20\% (Fig. 2B). Similar expression kinetics were observed in human A549 cells expressing endogenous wildtype p53. In normal human fibroblasts (MRC5) transduced by Adp $53 \mathrm{wt}, \mathrm{p} 53$ protein levels were still almost $50 \%$ of the peak concentration at day 9 . The level of p53 in vector-infected human cells was estimated to be 10- to 15-fold higher than endogenous levels in A549 and MRC5 cells. Because the antibody OP43 is specific for human p53, p53 protein was not detected in uninfected murine cells (day 0 ). Together, these data indicate that wild-type p53 can be over-expressed in murine and human cells over a period of at least 9 days after infection with Adp53wt.

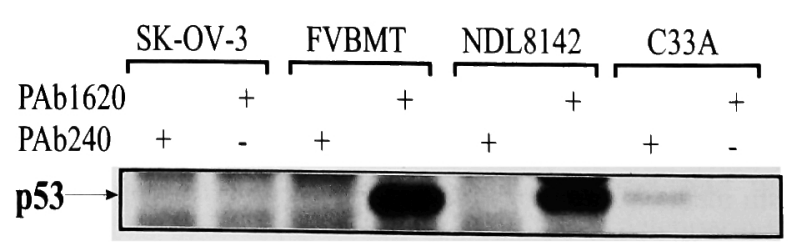

FIG. 1. Analysis of the endogenous p53 gene status in primary FVBMT and NDL8142 mammary adenocarcinoma cells by immunoprecipitation. The p53 protein was detected by the monoclonal PAb1620 antibody specific for wild-type protein and the mutant specific PAb240 antibody (Oncogene). SK-OV3 cells ( $\mathrm{p} 53$ negative) and $\mathrm{p} 53$ mutant $\mathrm{C} 33 \mathrm{~A}$ cells were used as controls. ${ }^{35} \mathrm{~S}$-Labeled proteins were subjected to $10 \%$ SDSPAGE. 

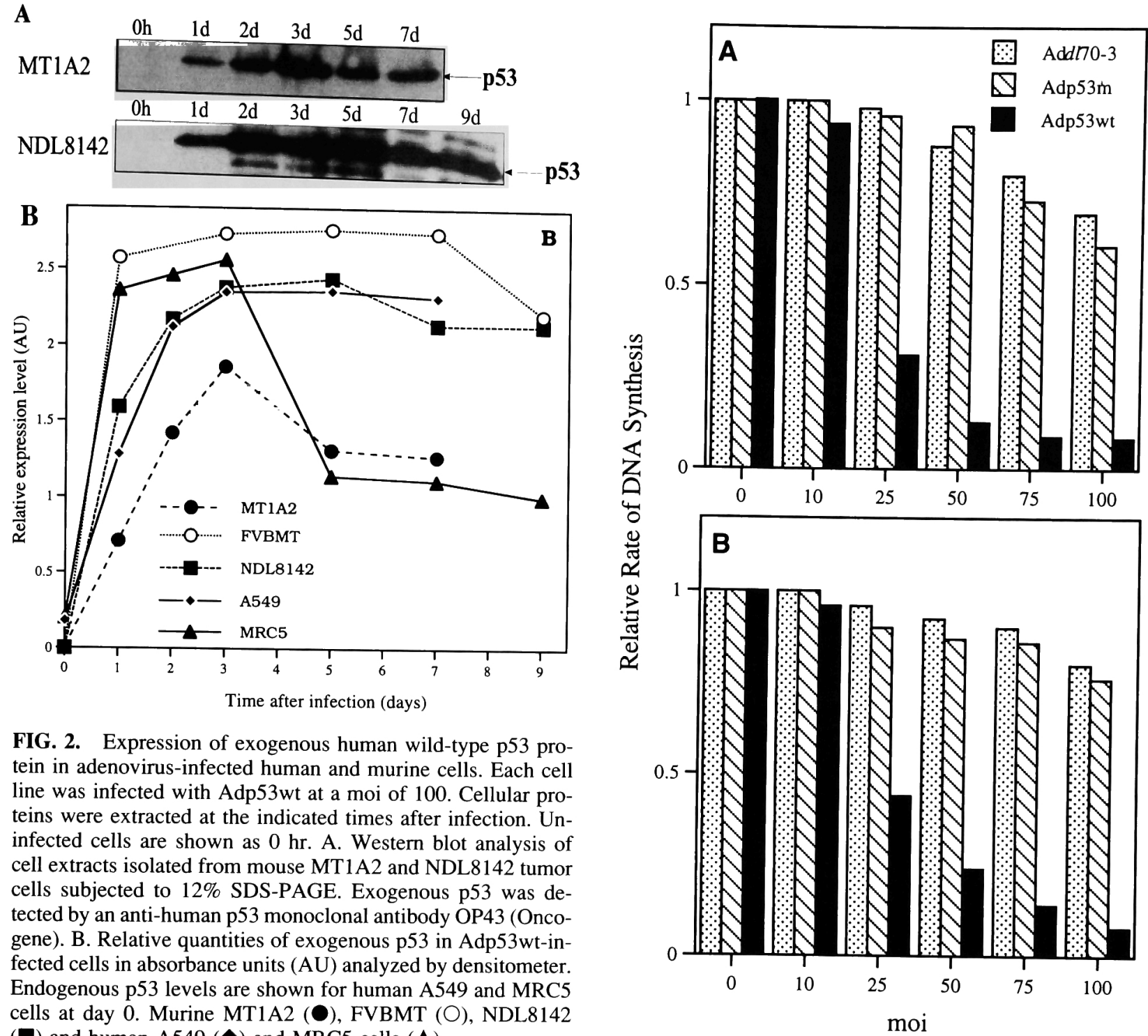

FIG. 2. Expression of exogenous human wild-type p53 protein in adenovirus-infected human and murine cells. Each cell line was infected with Adp53wt at a moi of 100. Cellular proteins were extracted at the indicated times after infection. Uninfected cells are shown as $0 \mathrm{hr}$. A. Western blot analysis of cell extracts isolated from mouse MT1A2 and NDL8142 tumor cells subjected to $12 \%$ SDS-PAGE. Exogenous p53 was detected by an anti-human p53 monoclonal antibody OP43 (Oncogene). B. Relative quantities of exogenous p53 in Adp53wt-infected cells in absorbance units (AU) analyzed by densitometer. Endogenous p53 levels are shown for human A549 and MRC5 cells at day 0. Murine MT1A2 (O), FVBMT (O), NDL8142 $(\boldsymbol{\square})$ and human A549 ( ) and MRC5 cells ( $\mathbf{A})$.

Inhibition of tumor cell growth by exogenous wild-type p53 in vitro

Introduction of p53wt expressed by the Ad vectors used in this study has been shown to inhibit cell proliferation and DNA synthesis of human p53-negative cells (Bacchetti and Graham, 1993). To determine whether over-expression of human p53 affects DNA synthesis and cell division of murine cell lines expressing endogenous wild-type p53, MT1 A2 cells (Fig. 3A) and NDL8142 cells (Fig. 3B) were infected with Adp53wt at different moi ranging from 5 to $100 \mathrm{pfu} / \mathrm{cell}$. Cells were reseeded after 4 days and DNA replication was measured $24 \mathrm{hr}$ later by $\left[{ }^{3} \mathrm{H}\right]$ thymidine incorporation, comparing DNA synthesis in Adp53wt versus Adp53m and Addl70-3 infected cells as controls (Fig. 3A,B). In both Adp53wt-infected cell lines, DNA synthesis was inhibited up to $92 \%$, whereas inhibition by Adp $53 \mathrm{~m}$ was similar to that caused by Ad $d l 70-3$ infection (only $20-40 \%$ at moi 100). To examine the effect of p53 on cell division, we infected both mammary carcinoma cells and normal MRC5 fibroblasts with Adp53wt at a moi of 100 and measured

FIG. 3. Effect of moi on DNA synthesis by $\left[{ }^{3} \mathrm{H}\right]$ thymidine incorporation assay. MT1A2 cells (A) and NDL8142 cells (B) were infected near confluency with Adp53wt, Adp53m, or the control Add $l 70-3$ at the indicated moi. After 4 days, the cells were reseeded at $5 \times 10^{4}$ cells $/ 60-\mathrm{mm}$ dish and values for $\left[{ }^{3} \mathrm{H}\right]$ thymidine incorporation were measured $24 \mathrm{hr}$ later as averages from duplicate cultures and expressed as a ratio relative to mock-infected cells by liquid scintillation counter.

cell number over a period of 5 days (Fig. 4A-C). Growth of Adp53wt-infected MT1A2 (Fig. 4A) and NDL8142 (Fig. 4B) cells was significantly suppressed over 3 days. Thereafter, it appeared that inhibition of MT1A2 cell growth was more pronounced as evidenced by a net decrease in cell number, whereas NDL8142 cells resumed growth, although at a reduced rate compared to the controls. Morphological changes were observed in both cell lines, with cells rounding up at day 3 in MT1A2 and day 5 in NDL8142 cells infected with Adp53wt (data not shown). In contrast, over-expression of wild-type p53 had no obvious effect on the growth rate of karyotypically normal human MRC5 fibroblasts (Fig. 4C). These findings indi- 

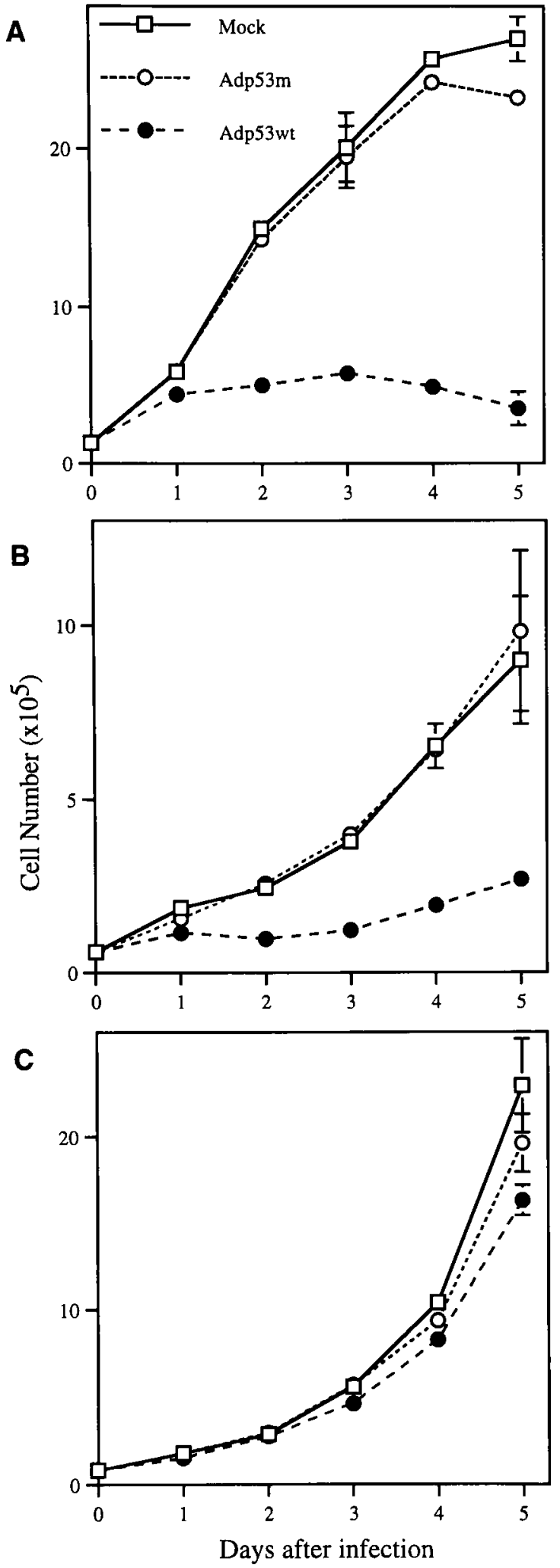

FIG. 4. Growth inhibition of Adp53wt-infected cells determined by a cell count assay. MT1A2 cells (A), NDL8142 cells (B), or MRC5 cells (C) were seeded at $5 \times 10^{4}$ cells $/ 60-\mathrm{mm}$ dish $24 \mathrm{hr}$ prior to infection with Adp53wt (O) or Adp53m (O) at moi 100 . At indicated time points triplicate dishes of each treatment were counted over 5 days after infection relative to mock-infected $(\square)$ cells. Cell viability was determined by trypan blue exclusion. cate that over expression of human p53 efficiently inhibits cell proliferation of murine tumor cells, in spite of endogenous murine p53wt expression.

\section{Induction of apoptosis in Adp53wt-infected tumor cells} and kinetics of IL-2 expression

To investigate whether apoptosis is the mechanism by which over expression of wild-type p53 protein inhibits cell growth in Adp53wt-infected MT1A2 and NDL8142 cells, DNA from uninfected and Addl70-3, AdIL-2, Adp53wt, or Adp53wt plus AdIL-2-infected cells was analyzed for DNA fragmentation into nucleosomal units. As shown in Fig. 5, a typical DNA laddering pattem consistent with apoptosis was evident at day 3 for MT1A2 cells infected with Adp53wt (Fig. 5A, lanes 5 and 6) and 2 days later in infected NDL8142 cells (Fig. 5B, lanes 10 and 11) correlating with relative effects on growth rates. At 3 days after infection, $23 \%$ of MT1A2 cells infected with Adp53wt were identified as apoptotic by fluorescence microscopy following Hoechst 33342 bis-benzimidazole staining (Ormerod et al., 1993), whereas only 1.6\% of Addl70-3-infected cells were apoptotic (data not shown). The percentage of apoptotic MT1A2 cells by Hoechst stain increased to $42 \%$ at day 5 after Adp53wt infection, but at this later time nucleosome-sized DNA fragments (approximately 14\%) were also evident in Addl70-3- and AdIL-2-treated cells (Fig. 5A, lanes 8 and 9). In contrast, even 5 days after infection, normal MRC5 fibroblasts transduced by these Ad vectors showed only a band at a high molecular weight corresponding to intact DNA (data not shown). These results indicate that wild-type p53 over-expression can induce apoptosis in murine mammary carcinoma cells. Later in infection but to a lesser extent, apoptosis also appeared to be induced by the replication-defective vector or by AdIL-2, at least in a fraction of infected murine tumor cells.

We next wished to determine whether $\mathrm{p} 53$ over-expression might interfere with expression of IL-2 in cells co-infected with Adp53wt and AdIL 2. IL-2 production by AdIL-2-infected cells was quantified by ELISA and compared to expression in cells infected with both Adp53wt plus AdIL-2. Mock-, Addl70-3-, and Adp53wt-infected cells were used as controls. AdIL-2-infected MT1A2 and NDL8142 cell lines were found to produce high amounts of IL-2 between days 3 and 5 after infection $\left(\sim 1-2 \mu \mathrm{g}\right.$ of IL-2/10 $10^{6}$ cells) (Fig. $5 \mathrm{C}$ ). IL-2 expression was reduced in the supernatants of cells that were infected with both AdIL-2 and Adp53wt (Fig. 5C), suggesting that the cellular events triggered by $\mathrm{p} 53$ affect $\mathbb{I L}-2$ production. This is not surprising in view of the effects of Adp53wt infection on DNA synthesis and cell growth seen in Figs. 3 and 4 . Nevertheless, the relative high level of IL- 2 produced by these cells even at 5 days after infection (about $0.6-0.9 \mu \mathrm{g}$ of $\mathrm{IL}-2 / 10^{6}$ cells) should be sufficient for biological activity in treated mice.

\section{Antitumoral activity of Adp53wt/AdlL-2-combination treatment on established breast tumors}

We have found that AdIL-2 was effective at eliciting tumor regression in about $50 \%$ of treated animals at a dose of $5 \times 10^{8}$ pfu (Addison et al., 1995; Addison et al., unpublished). However, AdIL-2 treatment seems to have a narrow window of activity: At doses sufficiently high to induce tumor regression, AdIL2 was also toxic and often resulted in a high mortality of 
A

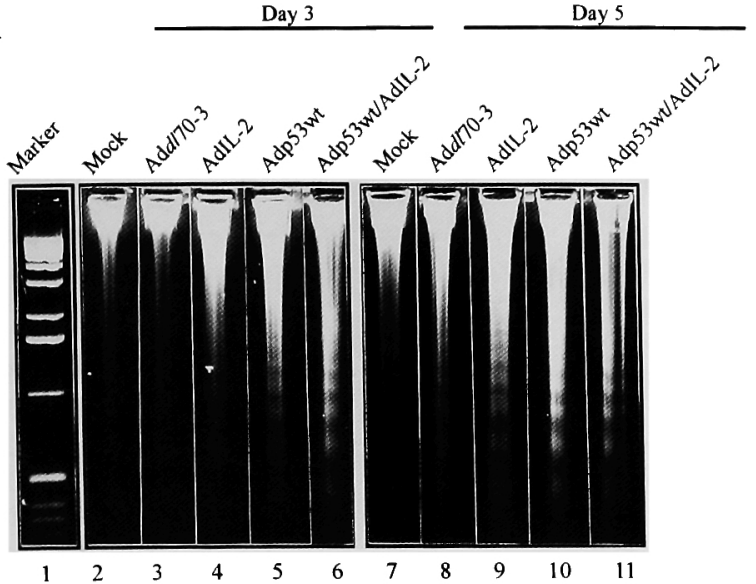

B

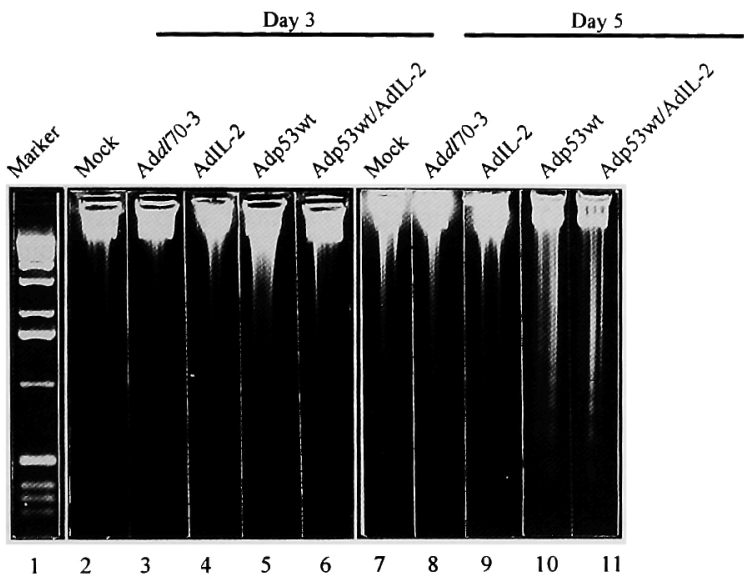

C

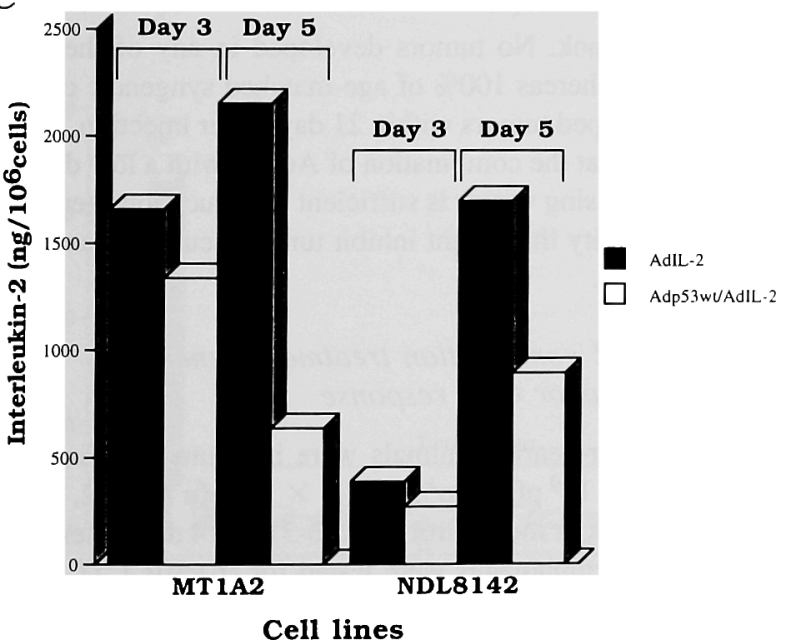

FIG. 5. Induction of apoptosis in Adp53wt-infected cells and expression kinetics of AdIL-2. In vitro DNA fragmentation analysis of MT1A2 cells (A) and NDL8142 cells (B) at days 3 and 5 after infection with Addl70-3 (lanes 3 and 8), AdIL-2 (lanes 4 and 9), Adp53wt (lanes 5 and 10), and the combination of Adp53wt/AdIL-2 (lanes 6 and 11) compared to mockinfected cells (lane 2). A 1-kb ladder served as a molecular marker (lane 1). C. Levels of IL-2 secreted by virus-infected cells shown in A an B at days 3 and 5 after infection. Cells were infected with virus at moi 100, using Adp53wt at moi 90 and/or AdIL-2 at moi 10. injected mice, whereas lower, nontoxic doses (less than $5 \times 10^{8}$ pfu) were ineffective (Addison et al., in preparation; this study). In agreement with our findings, Toloza and colleagues (1996) observed delayed growth and rejection of some established fibrosarcoma and mammary carcinoma with a cumulative virus dose of $2-6 \times 10^{9}$ pfu divided into two or three injections. Lower doses were ineffective and higher doses resulted in systemic IL-2 toxicity and animal death. For this reason, we sought to determine whether combining AdIL-2 treatment with an Advector encoding the wild-type p53 antiproliferative gene might allow a reduction in the amount of AdIL-2 to a nontoxic concentration while retaining the ability to induce complete tumor regression. PyMT-induced FVBMT tumors were injected with a mixture of AdIL-2 at a relatively low dose $\left(1.5 \times 10^{8} \mathrm{pfu}\right)$ combined with Adp53wt at $1 \times 10^{9} \mathrm{pfu}$, and monitored for regression in comparison to tumors injected only with AdIL-2, Adp53wt, or the Addl70-3 control virus. The Ad-vector expressing human wild-type p53 was initially tested in the PyMT transgenic model at several doses and showed strong tumor growth suppression (but no complete regressions) at $5 \times 10^{8}$ and $1 \times 10^{9} \mathrm{pfu}$, the highest dose used (data not shown). Representative data from one of four experiments are shown for tumor volume (Fig. 6A), and the combined data from four experiments for survival of mice are shown in Fig. 6B. Injection of either the control virus Addl70-3 or AdIL-2 alone failed to prevent tumor growth, but AdIL-2 treatment resulted in a delay in tumor growth over 10 days compared to Addll70-3-injected animals (Fig. 6A). A slight decrease in mean tumor volume at 5 days after injection $\left(59 \pm 22 \mathrm{~mm}^{3}\right.$ to $\left.38 \pm 4 \mathrm{~mm}^{3}\right)$ was seen in Adp53wt-treated mice, but this was followed by subsequent tumor regrowth. A more pronounced effect on tumor growth was observed after injection of Adp53wt plus AdIL-2, which caused a substantial regression from a mean tumor volume of $40 \pm 17 \mathrm{~mm}^{3}$ at the time of injection to $8 \pm 7$ $\mathrm{mm}^{3}$ at day 5 (Fig. 6A). Compared to Add $l 70-3$-treated control animals, survival of AdIL-2-treated mice was prolonged by about 2 weeks, and of Adp53wt-treated animals by 3 weeks (Fig. 6B). However, in all three groups, the tumors grew progressively following treatment and none underwent complete regression (results from Fig. 6 are summarized in Table 1). In contrast, injection of Adp53wt in combination with AdIL-2 induced complete regression in 50\% of tumors (10/20), and an additional $15 \%$ of treated mice $(3 / 20)$ showed a partial response resulting in disappearance of tumor mass for at least 2 weeks before tumor regrowth (Table 1). Tumor development in the remaining animals $(35 \%)$ was significantly delayed and survival was increased for 5 weeks compared to controls (Table 1, Fig. 6B). It should be mentioned that we did not observe any toxic side effects from the combination treatment. In contrast, $40 \%$ of the mice injected with $5 \times 10^{8}$ pfu of the IL-2-expressing vector alone died after treatment. In surviving animals, this dose of AdIL-2 induced complete tumor regression in $49 \%$ of mice (24/49). In $36 \%$ of injected animals (18/49), the tumor first disappeared and reoccurred within 2 weeks (Table 1).

Although previous reports have shown that the in vivo effects of an Ad-vector expressing wt p53 are dose dependent and are independent of the endogenous wild-type or mutant p53 status of the cells (Clayman et al., 1995), we cannot exclude the possibility that PyMT interferes with a downstream effector of p53. Therefore, we tested the efficacy of a Adp53wt plus AdIL- 

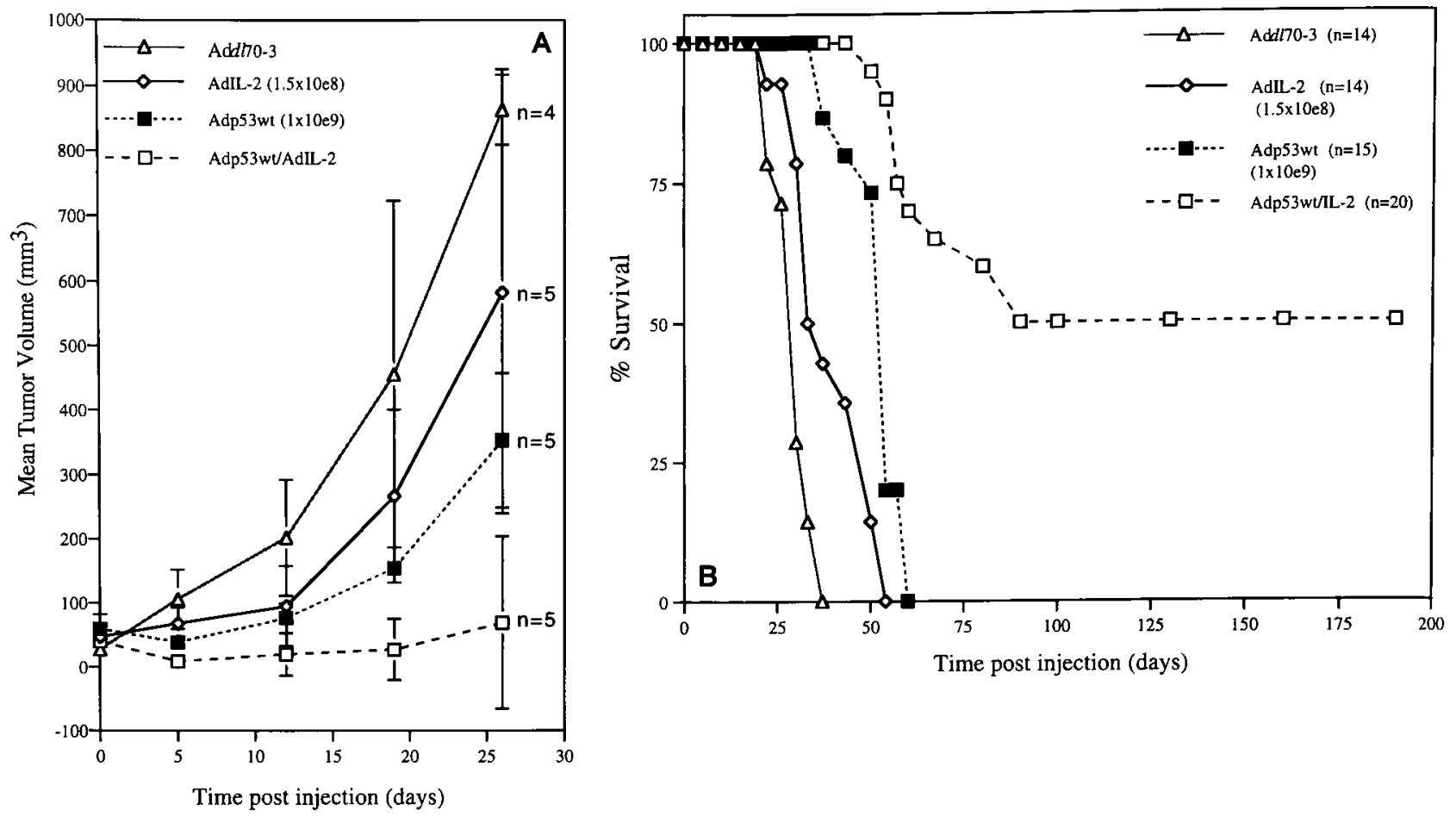

FIG. 6. Antitumoral activity of Adp53wt/AdIL-2-combination treatment on established PyMT breast tumors. FVBMT-induced tumors were injected with either $1.5 \times 10^{8}$ pfu of AdIL-2, $1 \times 10^{9}$ pfu of Adp53WT, or the combination of $1 \times 10^{9}$ pfu of Adp53wt and $1.5 \times 10^{8}$ pfu AdIL-2. Addl70-3 was used as a control. A. Mean tumor volume of mice from one representative experiment was measured every 5-7 days: $(\triangle)$ Addl70-3 $(n=4) ;(\diamond)$ AdIL-2 $\left(1.5 \times 10^{8}\right.$ pfu; $\left.n=5\right) ;(\square)$ Adp53wt $(n=5) ;(\square)$ Adp53wt/AdIL-2 $(n=5)$. B. Long-term survival of the total fraction of mice treated with the viruses shown in A. The survival of the experimental animal is plotted as a function of time.

2 combination treatment in a second transgenic mouse breast cancer model expressing a (MTMV)/neu fusion gene carrying a deletion corresponding to Neu8142 (Siegel et al., 1994; Siegel and Muller, 1996). In the neu model, growth of tumors injected with Adp53wt was significantly inhibited over 10 days after treatment and $1 / 5$ mice showed a partial regression over 2 weeks and survived 2 months longer than the controls (data not shown). Again in this model, clearance of tumors was seen only in the group treated with the combination of AdIL-2 and Adp53, but compared to the PyMT model, the efficiency of complete regression was somewhat lower (3/10 mice). Moreover, AdIL2 alone even at $5 \times 10^{8}$ pfu had no significant effect on tumor growth (data not shown) and was also not associated with toxic side effects, which may explain the lower percentage of complete regressions seen with the AdIL-2/Adp53wt combination therapy. None of the mice injected with Addl70-3 showed evidence of a response.

\section{Tumor regression by combination treatment is associated with long-term immunity}

One major goal of cytokine immunotherapy is the induction of antitumor immunity and protection against recurrence and metastasis. To test whether PyMT transgenic mice cured by the combination treatment with Ap53wt plus AdIL-2 $\left(1.5 \times 10^{8}\right.$ pfu) were protected against a second inoculation with tumor cells, we rechallenged 5 tumor-free mice $2-3$ months after regression by injecting $10^{6}$ fresh tumor cells subcutaneously into the opposite flank. No tumors developed in any of the challenged mice, whereas $100 \%$ of age-matched syngeneic control animals developed tumors within 21 days after injection. These data indicate that the combination of Adp53 with a low dose of the IL-2-expressing vector is sufficient to induce long-term antitumor immunity that might inhibit tumor recurrence and prevent metastasis.

\section{Adp53/AdIL-2 combination treatment generates specific antitumor $C T L$ response}

PyMT tumor-bearing animals were intratumorally injected with either $1 \times 10^{9}$ pfu Adp53wt, $1.5 \times 10^{8} \mathrm{pfu}$ AdIL-2, AdIL2 plus Adp53wt, or the control Add $l 70-3$ and 14 days after treatment splenic lymphocytes were tested for specific CTL activity against middle $\mathrm{T}$ antigen-expressing cells by ${ }^{51} \mathrm{Cr}$ release. In the group treated with the combination of Adp53 and AdIL2,2 of 3 mice were tumor free at day 6 after injection. Splenic cells obtained from these mice showed a significant antitumor CTL response with a specific lysis of 50 and $70 \%$, respectively, at an effector-to-target ratio of 10:1, whereas specific lysis in all other tumor-bearing mice, independent of their treatment, was below 7\% (Fig. 7). No response was observed in any of the treatment groups against nonspecific control target cells. The presence of CTL specific for tumor antigen in the group injected with the combination of Adp53 and AdIL-2 confirms that tumor regression is associated with development of antitumor immunity. 
Table 1. Induction of Tumor Regression by Intratumoral Injection of Adp53wt and AdIL-2 ${ }^{a}$

\begin{tabular}{|c|c|c|c|c|c|}
\hline Virus & $\begin{array}{l}\text { Total } \\
\text { exp. }\end{array}$ & $\begin{array}{l}N o^{\mathrm{b}} \\
\text { response }\end{array}$ & $\begin{array}{l}\text { Growth }^{\mathrm{c}} \\
\text { delay }\end{array}$ & $\begin{array}{l}\text { Partial }^{\mathrm{d}} \\
\text { regression }\end{array}$ & $\begin{array}{l}\text { Complete } \\
\text { regression }\end{array}$ \\
\hline Add $l l 70-3$ & $(n=14)$ & $14 / 14$ & - & 0 & 0 \\
\hline $\begin{array}{l}\text { AdIL-2 } \\
\left(1.5 \times 10^{8}\right)\end{array}$ & $(n=14)$ & $\begin{array}{c}3 / 15 \\
(20 \%)\end{array}$ & $\begin{array}{l}12 / 15 \\
(80 \%)\end{array}$ & 0 & 0 \\
\hline $\begin{array}{l}\text { AdIL-2 } \\
\left(5 \times 10^{8}\right)\end{array}$ & $(n=49)$ & $\begin{array}{c}7 / 49 \\
(14 \%)\end{array}$ & $0 / 49$ & $\begin{array}{l}18 / 49 \\
(36 \%)\end{array}$ & $\begin{array}{l}24 / 49 \\
(49 \%)\end{array}$ \\
\hline $\begin{array}{l}\text { Adp53wt } \\
\left(1 \times 10^{9}\right)\end{array}$ & $(n=15)$ & $0 / 15$ & $\begin{array}{c}15 / 15 \\
(100 \%)\end{array}$ & 0 & 0 \\
\hline $\begin{array}{l}\text { Adp53wt } \\
\left(1 \times 10^{9}\right) \\
+ \text { AdIL-2 } \\
\left(1.5 \times 10^{8}\right)\end{array}$ & $(n=20)$ & $0 / 15$ & $\begin{array}{l}7 / 20 \\
(35 \%)\end{array}$ & $\begin{array}{c}3 / 20 \\
(15 \%)\end{array}$ & $\begin{array}{l}10 / 20 \\
(50 \%)\end{array}$ \\
\hline
\end{tabular}

${ }^{a}$ Cumulative data from four experiments.

${ }^{\mathrm{b}}$ Tumor development following injection not significantly different from mice treated with control Addl70-3.

'Slight decrease in tumor volume and/or tumor growth significantly delayed and animals survived 2-8 weeks longer than controls.

dTumors completely regressed for at least 2 weeks but reoccurred.

'Tumors completely regressed and did not reoccur.

fSummarized data from 11 experiments. Treatment was associated with $40 \%$ mortality. Dead mice are excluded from subsequent calculations.

\section{DISCUSSION}

The transfer of genes involved in cell cycle repression and restoration of the apoptotic pathway in cancer cells, combined with genes that help to induce antitumor immunity, provides a promising approach for in vivo treatment of primary and metastatic cancer.

In this study, we examined the efficacy of the combination

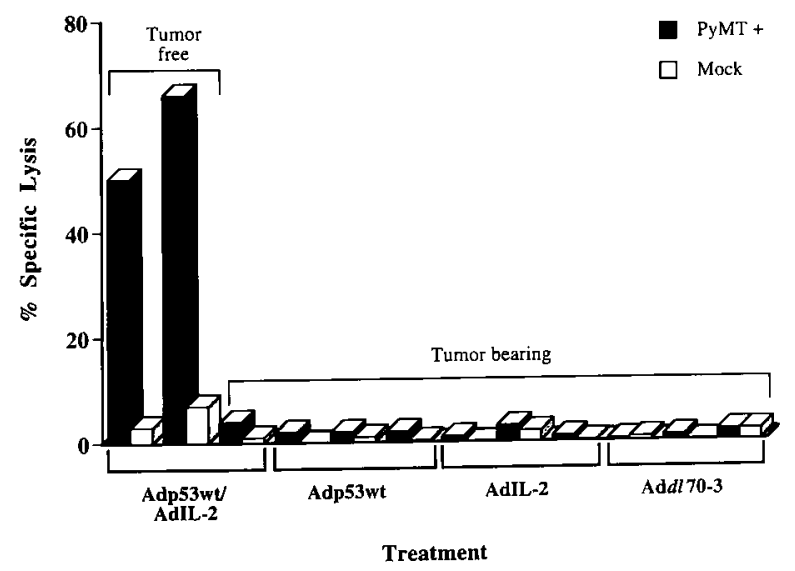

FIG. 7. Generation of specific antitumor CTL response by Adp53wt/AdIL-2 combination therapy. Splenic lymphocytes from tumor-free and tumor-bearing mice after treatment with the combination Adp53wt/AdIL-2 $\left(1 \times 10^{9} \mathrm{pfu} / 1.5 \times 10^{8} \mathrm{pfu}\right)$, Adp53wt $\left(1 \times 10^{9} \mathrm{pfu}\right)$, AdIL-2 $\left(1.5 \times 10^{8} \mathrm{pfu}\right)$ or the control virus Add $l 70-3\left(1.15 \times 10^{9} \mathrm{pfu}\right)$ were stimulated with irradiated PyMT expressing 516MT3 cells in a ratio of 100:1 for a period of 5 days. Each group consisted of 3 animals. ${ }^{51} \mathrm{Cr}$-labeled 516MT3 cells or nonspecific control cells were used as targets and specific lysis was determined at an effector/target ratio of 10:1. Specific ${ }^{51} \mathrm{Cr}$-release was calculated as described (Bramson et al., 1996). of the p53 and IL-2 genes for antitumor response. Both genes were integrated into adenoviral vectors and transferred alone or in combination directly into murine mammary adenocarcinomas. Analysis of the endogenous p53 status in the tumor cell lines derived from the transgenic models suggested that both cell lines expressed wild-type p53 protein, in agreement with previous studies indicating that polyomavirus-induced tumorigenesis does not require a dominantly acting p53 mutation (Qian et al., 1997).

Our in vitro results demonstrate that exogenous human p53 can be efficiently transduced and expressed in murine cells by an Ad-vector. High levels of wild-type p 53 protein, detected over at least 9 days after infection, significantly inhibited growth of both transgenic tumor cell lines compared to mockor Adp53m-infected cells, suggesting that the growth-inhibiting effect is not mediated by the virus itself. However, tumor cell growth was not absolutely or permanently inhibited, suggesting that either a small fraction of the murine cell population was resistant to the effects of human p53 or some cells failed to express the transduced gene even after infection at 100 pfu/cell. Concomitantly with a decrease in MT1A2 cell number between days 3 and 5 after infection, apparent morphological changes were obvious, with nearly half the cells rounding up and displaying severe chromatin condensation (unpublished data). At this time, we also observed characteristic nucleosomal units in a DNA fragmentation assay, suggesting that apoptosis is a likely mechanism for suppression of growth in Adp53wt-infected breast cancer cells. Features of apoptosis occurred earlier in MT1A2 than in NDL8142 cells, but were evident in both cell lines. It is known from previous studies that the induction of cell growth suppression and apoptosis by wildtype p53 over-expression is independent of the endogenous p53 status in tumor cells (Liu et al., 1994, 1995).

From gel electrophoretic analysis of infected cell DNA and microscopy, apoptosis was also evident at day 5 after infection in a small fraction of Addl70-3- or AdIL-2-infected MT1A2 
and NDL8142 tumor cells. It is known that E1A proteins induce apoptosis in cells lacking p53 (Subramanian et al., 1995), and recent results have indicated that adenoviral early region 4 products are responsible for p53-independent cell death at late times after infection with Ad5 vectors lacking E1 and E3 (Marcellus et al., 1996). Cellular proteins that can functionally substitute for E1A as a transactivator of early and late promoters have been found in several cell lines derived from human malignant tumors (Imperiale et al., 1984), and these proteins may induce expression of the $\mathrm{E} 4$ region, thus explaining the small amount of apoptotic cells found at a later time of adenovirus infection.

As reported previously, introduction of AdIL-2 alone (Addison et al., 1995) can induce regression of established tumors in the PyMT transgenic breast cancer model. Although the short half life of IL2 in vivo would suggest that expression of the cytokine by tumor cells transduced with AdIL 2 should be more effective than intratumoral injection with recombinant IL-2, this has not been demonstrated by direct side-by-side comparisons either in earlier studies or in the present experiments. Furthermore, intratumoral injection with an Ad expression vector may not overcome the problem of side effects due to $\mathrm{IL}-2$ and, in fact, at doses needed to induce regression, AdIL2 treatment is associated with significant toxicity (Toloza et al., 1996; Addison et al., in preparation). In further studies, using an increased number of animals, we found that intratumoral injection of $5 \times$ $10^{8}$ pfu AdIL-2 caused complete tumor regression in $49 \%$ of the mice, but resulted in obvious IL-2-related toxic side effects causing death of $40 \%$ of animals around day 12 after treatment (Addison et al., in preparation; present study). Thus, our results and those of studies reported by Toloza et al. (1996) indicate that AdIL-2 treatment has a narrow therapeutic window and that doses greater than 4 to $6 \times 10^{9}$ pfu have a growth inhibitory effect but result in systemic IL-2 toxicity and death.

We demonstrate here that the combination of AdIL-2 with a wild-type p53-expressing Ad-vector induced a greater antitumor response than either vector alone and permitted use of a nontoxic AdIL-2 dose. Whereas the low dose of AdIL-2 alone was sufficient to induce growth retardation in the majority of mice, Adp53wt injection slightly decreased PyMT tumor volume and caused a delay in tumor growth in $100 \%$ of injected mice. A substantial reduction of tumor volume was present in mice injected with the combination of AdIL-2 plus Adp53, and only the combination treatment produced tumor regression: $100 \%$ of the animals responded to treatment with AdIL-2 plus Adp53 and 50\% of the treated mice remained tumor free. Furthermore, none of the treated animals showed toxic effects attributable to the combination therapy. Because infection of Advectors intratumorally resulted in transduction of only a fraction of the tumor cells (as little as 20\%; Addison et al., unpublished data), it appears unlikely that the observed effect of Adp53wt on tumor growth is directly mediated by intracellular wt p53 protein. It is possible that bystander effects may provide transient growth inhibition by Adp53. A previous study has shown that p53 inhibition of human breast tumors closely correlates with a reduction of blood vessel density in the tumor, suggesting that p53 effects are mediated, at least in part, by an antiangiogenesis mechanism (Xu et al., 1997). This is interesting in view of a recently published work illustrating that PyMT tumors are highly angiogenic (Cheung et al., 1997). In the case of combination treatment, activation of certain immune functions may potentiate such bystander effects.

Combination treatment induced protective immunity in all mice cured of tumors. That $\mathrm{L}-2$ expression is associated with the induction of antitumor immunity has been demonstrated previously either by using AdIL-2 alone (Addison et al., 1995a; Huang et al., 1996), or in combination with other genes such as herpes simplex thymidine kinase (Chen et al., 1995; O'Malley et al., 1996). It has been shown that the IL-2 level produced by genetically modified tumor cells (Schmidt et al., 1995) or fibroblasts (Fakhrai et al., 1995) is critically important in determining protection efficiency. Best immunization was achieved with tumor vaccines producing intermediate $\mathrm{IL}$ 2 levels; lower cytokine secretion reduced the number of successfully treated animals and high-level expression completely abolished protection. When Adp53wt is used in conjunction with AdIL-2 in vivo, p53 expression transiently slows tumor growth, which may allow IL-2 to activate immunity at a significantly lower dose.

Cytotoxic $\mathrm{T}$ cell assays provided evidence that the induction of an immune response against PyMT-expressing tumor cells occurred in mice treated with Adp53wt plus AdIL-2, indicating that tumor regression observed after combination treatment is associated with the development of a specific cytotoxic $\mathbf{T}$ lymphocyte response. We have demonstrated that rejection of PyMT-expressing tumors is correlated with an activation of CTL activity after treatment with IL-2 or IL-12 encoding Ad vectors (Addison et al., in preparation; Bramson et al., 1997). CTL activity was detectable when tumors began to regress following treatment but the activity dissipated when the tumors relapsed (Bramson, unpublished data), suggesting that tumor growth might counteract CTL activity. Therefore, we argue that tumor growth inhibition by p53 expression is an important mechanism to support the expansion of a specific CTL response, initiated by the IL-2. Of course, detection of CTL activity against PyMT does not preclude the possibility that CTLs are also induced against other tumor antigens. We have not attempted to challenge mice that are protected against PyMT cells with other murine tumors such as the NDL tumor cells to test for the presence of common protective antigens. In conclusion, the present study provides support for combination gene therapy with an immunomodulatory and antiproliferative gene as a promising approach in cancer treatment.

\section{ACKNOWLEDGMENTS}

We thank John Rudy and Derek Cummings for excellent technical assistance and Silvia Bacchetti for reviewing the manuscript. This work was supported by grants from the National Cancer Institute of Canada (NCIC), the Medical Research Council of Canada (MRC), the Canadian Breast Cancer Initiative, and London Life Insurance. F.L. Graham is a Terry Fox Scientist of the NCIC and W.J. Muller is a MRC Scientist. B.M. Pützer is supported by a post-doctoral fellowship of the Deutsche Krebshilfe, Mildred-Scheel Stiftung, J.L. Bramson was a MRC post-doctoral fellow and C.L. Addison was supported by the NCIC. All animal work has been approved by and carried out according to guidelines set by the Animal Research Ethics Board of McMaster University. 


\section{REFERENCES}

ADDISON, C.L., BRACIAK, T., RALSTON, R., MULLER, W.J., GAULDIE, J., and GRAHAM, F.L. (1995). Intratumoral injection of an adenovirus expressing interleukin 2 induces regression and immunity in a murine breast cancer model. Proc. Natl. Acad. Sci. USA 92, 8522-8526.

ADDISON, C.L., HITT, M., KUNSKEN, D., and GRAHAM, F.L. (1997). Comparison of the human versus murine cytomegalovirus immediate early gene promoters for transgene expression by adenoviral vectors. J. Gen. Virol. 78, 1653-1661.

ASGARI, K., SESTERHENN, I.A., MCLEOD, D.G., COWAN, K., MOUL, J.W., SETH, P., and SRIVASTAVA, S. (1997). Inhibition of the growth of pre-established subcutaneous tumor nodules of human prostate cancer cells by single injection of the recombinant adenovirus p53 expression vector. Int. J. Cancer 71, 377-382.

BACCHETTI, S., and GRAHAM, F.L. (1993). Inhibition of cell proliferation by an adenovirus vector expressing the human wild type p53 protein. Int. J. Oncol. 3, 781-788.

BANNERJ, R., ARROYO, C.D., CORDON-CARDO, C., and GILBOA, E. (1994). The role of IL-2 secreted from genetically modified tumor cells in the establishment of antitumor immunity. J. Immunol. 152, 2324-2332.

BERG, J.W. (1971). Morphological evidence for immune response to breast cancer. A historical review. Cancer 28, 1453-1456.

BETT, A.J., HADDARA, W., PREVEC, L., and GRAHAM, F.L. (1994). An efficient and flexible system for construction of adenovirus vectors with insertions or deletions in early regions 1 and 3 . Proc. Natl. Acad. Sci. USA 91, 8802-8806.

BRAMSON, J.L., HITT, M., GALLICHAN, W.S., ROSENTHAL, K.L., GAULDIE, J., and GRAHAM, F.L. (1996a). Construction of a double recombinant adenovirus vector expressing a heterodimeric cytokine: In vitro and in vivo production of biologically active interleukin-12. Hum. Gene Ther. 7, 333-342.

BRAMSON, J.L., HITT, M., ADDISON, C.L., MULLER, W.J., GAULDIE, J., and GRAHAM, F.L. (1996b). Direct intratumoral injection of an adenovirus expressing interleukin-12 induces regression and long-lasting immunity that is associated with highly localized expression of interleukin-12. Hum. Gene Ther. 7, 19952002.

BRAMSON, J.L., HITT, GAULDIE, J., and GRAHAM, F.L. (1997). Pre-existing immunity to adenovirus does not prevent tumor regression following intratumoral administration of a vector expressing IL12 but inhibits virus dissemination. Gene Ther. 4, 1069-1076.

BUBENIK, J. (1997). Gene therapy of malignant tumors. Prospects of cytokine gene transfer vaccines. Cas. Lek. Cesk. 136, 17-21.

BUCHMAN, N.J., CHUMAKOV, P.M., NINKINA, N.N., SAMARINA, O.P., and GEORGIEV, G.P. (1988). A variation in the structure of the protein-coding region of the human p53 gene. Gene $\mathbf{7 0}$, 245-252.

CAO, X.T., ZHANG, W.P., and TAO, Q. (1995). Enhanced immune functions and antitumor activity of fibroblast-mediated interleukin2 gene therapy. Chung Hua. I. Hsueh. Tsa. Chih. 75, 521-524.

CHEN, S.-H., CHEN, X.H.L., WANG, Y., KOSAI, K.-I., FINEGOLD, M.J., RICH, S.S., and WOO, S.L.C. (1995). Combination gene therapy for liver metastasis of colon carcinoma in vivo. Proc. Natl. Acad. Sci. USA 92, 2577-2581.

CHEUNG, A.T.W., YOUNG, L.J.T., CHEN, P.C.Y., CHAO, C.Y., NDOYE, A., BARRY, P.A., MULLER, W.J., and CARDIFF, R.D. (1997). Microcirculation and metastasis in a new mouse mammary tumor model system. Int. J. Oncol. 11, 69-77.

CIRIELlI, C., RICCIONI, T., YANG, C., PILI, R., GLOE, T., CHANG, J., INYAKU, K., PASSANITI, A., and CAPOGROSSI, M.C. (1995). Adenovirus-mediated gene transfer of wild-type p53 results in melanoma cell apoptosis in vitro and in vivo. Int. J. Cancer 63, 673-679.
CLARY, B.M., COVENEY, E.C., PHILIP, R., BLAZER, D.G., MORSE, M., GILBOA, E., and LYERLY, H.K. (1997). Inhibition of established pancreatic cancers following specific active immunotherapy with interleukin-2 gene-transduced tumor cells. Cancer Gene Ther. 4, 97-104.

CLAYMAN, G.L., EL-NAGGAR, A.K., ROTH, J.A., ZHANG, W.-W., GOEPFERT, H., TAYLOR, D.L., and LIU, T.-J. (1995). In vivo molecular therapy with p53 adenovirus for microscopic residual head and neck squamous carcinoma. Cancer Res. 55, 1-6.

DAMERON, K., VOPERT, O.V., TAINSKY, M.A. and BOUCK, N. (1994). Control of angiogenesis in fibroblast by p53 regulation of thrombospondin 1. Science 265, 1582-1584.

FAKHRAI, H., SHAWLER, D.L., GJERSET, R., NAVIAUX, R.K., KOZIOL, J., ROYSTON, I., and SOBOL, R.E. (1995). Cytokine gene therapy with interleukin-2-transduced fibroblasts: effects of IL2 dose on anti-tumor immunity. Hum. Gene Ther. 6, 591-601.

FEARON, E.R., PARDOLL, D., ITAYA, T., GOLUMBEK, P., LEVITSKY, H.I., SIMONS, J.W., KARASUYAMA, H., VOGELSTEIN, B., and FROST, P. (1990). Interleukin-2 production by tumor cells bypasses $\mathrm{T}$ helper function in the generation of antitumor response. Cell 60, 397-403.

GANSBACHER, B., ZIER, K., DANIELS, B., CRONIN, K., BANNERJI, R., and GILBOA, E. (1990). Interleukin 2 gene transfer into tumor cells abrogates tumorigenicity and induces protective immunity. J. Exp. Med. 172, 1217-1224.

GOMEZ-MANZANO, C., FUEYO, J., KYRITSIS, A.P., STECK, P.A., ROTH, J.A., MCDONNELL, T.J., STECK, K.D., LEVIN, V.A., and YUNG, W.K. (1996). Adenovirus-mediated transfer of the p53 gene produces rapid and generalized death of human glioma cells via apoptosis. Cancer Res. 56, 694-699.

GRAHAM, F.L., and PREVEC, L. (1991). Manipulation of adenovirus vectors. In Methods in Molecular Biology: Gene Transfer and Expression Protocols. E.J. Murray ed. (The Humana Press, Inc., Clifton, NJ) Vol. 7, pp. 109-128.

GRAHAM, F.L., SMILEY, J., RUSSELL, W.C., and NAIRN, R. (1977). Characteristics of a human cell line transformed by DNA from human adenovirus type 5. J. Gen. Virol. 36, 59-72.

GROSSER, N., and THOMSON, D.M. (1975). Cell-mediated antitumor immunity in breast cancer patients evaluated by antigen-induced leukocyte adherence inhibition in test tubes. Cancer Res. 35, 2571-2579.

GUY, C.T., CARDIFF, R.D., and MULLER, W.J. (1992). Induction of mammary tumors by expression of polyoma middle $\mathrm{T}$ oncogene: $\mathrm{A}$ transgenic mouse model for metastatic disease. Mol. Cell. Biol. 12, 954-961.

HAMADA, K., ALEMANY, R., ZHANG, W.-W., HITTELMAN, W.N., LOTAN, R., ROTH, J.A., and MTTCHELL, M.F. (1996). Adenovirus-mediated transfer of a wild-type p53 gene and induction of apoptosis in cervical cancer. Cancer Res. 56, 3047-3054.

HITT, M., BETT, A.J., PREVEC, L., and GRAHAM, F.L. (1994). Construction and propagation of human adenovirus vectors. In Cell Biology: A Laboratory Handbook. J.E. Celis, ed. (Academic Press, San Diego) pp. 479-490.

HOWARD, D.R. (1983). T-antigen does not induce cell mediated immunity in patients with breast cancer. Cancer 51, 2053-2056.

HSIAO, M., TSE, V., CARMEL, J., TSAI, Y., FELGNER, P.L., HAAS, M., and SILVERBERG, G.D. (1997). Intracavitary liposome-mediated p53 gene transfer into glioblastoma with endogenous wild-type p53 in vivo results in tumor suppression and long-term survival. Biochem. Biophys. Res. Commun. 233, 359-364.

HUANG, H., CHEN, S.H., KOSAI, K., FINEGOLD, M.J., and WOO, S.L. (1996). Gene therapy for hepatocellular carcinoma: Long-term remission of primary and metastatic tumors in mice by interleukin2 gene therapy in vivo. Gene Ther. 3, 980-987.

IMPERIALE, M.J., KAO, H.-T., FELDMAN, L.T., NEVINS, J., and STRICKLAND, S. (1984). Common control of the heat shock gene 
and early adenovirus genes: evidence of cellular E1A-like activity. Mol. Cell. Biol. 4, 867-874.

JOHNSON, P., GRAY, D., MOWAT, M., and BENCHIMOL, S. (1991). Expression of wild-type p53 is not compatible with continued growth of p53-negative tumor cells. Mol. Cell. Biol. 11, 1-11.

LIN, D., SHIELDS, M.T., ULLRICH, S.J., APPELLA, E., and MERCER, W.E. (1992). Growth arrest induced by wild-type p53 protein blocks cells prior to or near the restriction point in late Gl phase. Proc. Natl. Acad. Sci. USA 89, 9210-9214.

LIU, T.-J., ZHANG, W.-W., TAYLOR, D.L., ROTH, J.A., GOEPFERT, H., and CLAYMAN, G.L. (1994). Growth suppression of human head and neck cancer cells by the introduction of a wildtype p53 gene via a recombinant adenovirus. Cancer Res. 54, 3662-3667.

LIU, T.-J., EL-NAGGAR, A.K., McDONNELL, T.J., STECK, K.D., WANG, M., TAYLOR, D.L., and CLAYMAN, G.L. (1995). Apoptosis induction mediated by wild-type p53 adenoviral gene transfer in squamous cell carcinoma of the head and neck. Cancer Res. 55, 3117-3122.

LOTZE, M.T. (1996). Cytokine gene transfer of cancer. Cancer J. Sci. Am. 2, 63.

LUDWIG, C.U., HARTMANN, D., LANDMANN, R., WESP, M. ROSENFELDER, G., STUCKI, D., BUSER, M., OBRECHT, J.P. (1985). Unaltered immunocompetence in patients with non-disseminated breast cancer at the time of diagnosis. Cancer 55, 1673-1678.

MARCELLUS, R.C., TEODORO, J.G., WU, T., BROUGH, D.E., KETNER, G., SHORE, G.C., and BRANTON, P.E. (1996). Adenovirus type 5 early region 4 is responsible for ElA-induced p53-independent apoptosis. J. Virol. 70, 6207-6215.

MULLER, W.J., SINN, E., WALLACE, R., PATTENGALE, P.K., and LEDER, P. (1988). Single-step induction of mammary adenocarcinoma in transgenic mice bearing the activated c-neu oncogene. Cell 54, 105-115.

OHNO, T., YANG, Z., LING, X., JAFFE, M., NABEL, E.G., NORMOLLE, D., and NABEL, G.J. (1997). Combination gene transfer to potentiate tumor regression. Gene Ther. 4, 361-366.

O'MALLEY, B.W., COPE, K.A., CHEN, S.H., LI, D., SCHWARTA, M.R., and WOO, S.L. (1996). Combination gene therapy for oral cancer in a murine model. Cancer Res. 56, 1737-1741.

ORMEROD, M.G., SUN, X.-M., BROWN, D., SNOWDEN, R.T., and COHEN, G.M. (1993). Quantitation of apoptosis and necrosis by flow cytometry. Acta. Oncol. 32, 417-424.

PARMIANI, G., COLOMBO, M.P., MELANI, C., and ARIENTI, F. (1997). Cytokine gene transduction in the immunotherapy of cancer. Adv. Pharmacol. 40, 259-307.

PÜTZER, B.M., HITT, M., MULLER, W.J., EMTAGE, P., GAULDIE, J., and GRAHAM, F.L. (1997). Interleukin-12 and B7-1 costimulatory molecule expressed by an adenovirus vector act synergistically to facilitate tumor regression. Proc. Natl. Acad. Sci. USA 94, 10889-10894.

QIAN, W., KASHUBA, E., MAGNUSSON, K.P., POKROVSKAJA, K., OKAN, I., KLEIN, G., and WIMAN, K.G. (1997). Role of p53 mutation in polyomavirus-induced tumorigenesis. J. Gen. Virol. 78, 893-903.

ROTH, J.A., NGUYEN, D., LAWRENCE, D.D., KEMP, B.L., CARRASCO, C.H., FERSON, D.Z., HONG, W.K., KOMAKI, R., LEE, J.J., NESBITT, J.C., PISTERS, K.M.W., PUTNAM, J.B., SCHEA, R., SHIN, D.M., WALSH, G.L., DOLORMENTE, M.M., HAN, C.-I., MARTIN, F.D., YEN, N., XU, K., STEPHENS, L.C., MC-
DONNELL, T.J., MUKHOPADHYAY, T., and CAI, D. (1996). Retrovirus-mediated wild-type p53 gene transfer to tumors of patients with lung cancer. Nature. Med. 2, 985-991.

SANDIG, V., BRAND, K., HERWIG, S., LUKAS, J., BARTEK, J., and STRAUSS, M. (1997). Adenovirally transferred p16 ${ }^{\text {INK4/CDKN2 }}$ and 553 genes cooperate to induce apoptotic tumor cell death. Nature Med. 3, 313-319.

SCHMIDT, W., SCHWEIGHOFFER, T., HERBST, E., MAASS, G., BERGER, M., SCHLICHER, F., SCHAFFNER, G., and BIRNSTIEL, M.L. (1995). Cancer vaccines: The interleukin 2 dosage effect. Proc. Natl. Acad. Sci. USA 92, 4711-4714.

SIEGEL, P.M., and MULLER, W.J. (1996). Mutations affecting conserved cysteine residues within the extracellular domain of Neu promote receptor dimerization and activation. Proc. Natl. Acad. Sci. USA 93, 8878-8883.

SIEGEL, P.M., DANKORT, D.L., HARDY, W.R., and MULLER, W.J. (1994). Novel activating mutations in the neu proto-oncogene involved in induction of mammary tumors. Mol. Cell. Biol. 14, $7068-7077$.

SPITZ, F.R., NGUYEN, D., SKIBBER, J.M., CUSACK, J., ROTH, J.A., and CRISTIANO, R.J. (1996). In vivo adenovirus-mediated p53 tumor suppressor gene therapy for colorectal cancer. Anticancer Res. 16, 3415-3422.

SUBRAMANIAN, T., TARODI, B., and CHINNADURAI, G. (1995). p53-independent apoptotic and necrotic cell deaths induced by adenovirus infection: suppression by $\mathrm{E} 1 \mathrm{~B} 19 \mathrm{~K}$ and $\mathrm{Bcl}-2$ proteins. Cell Growth Differ. 6, 131-137.

SUN, W.H., BURKHOLDER, J.K., SUN, J., CULP, J., TURNER, J., LU, X.G., PUGH, T.D., ERSHLER, W.B., and YANG, N.-S. (1995). In vivo cytokine gene transfer by gene gun reduces tumor growth in mice. Proc. Natl. Acad. Sci. USA 92, 2889-2893.

TAN, Y., XU, M., WANG, W., ZHANG, F., LI, D., XU, X., GU, J., and HOFFMAN, R.M. (1996). IL-2 gene therapy of advanced lung cancer patients. Anticancer Res. 16, 1993-1998.

TOLOZA, E.M., HUNT, K., SWISHER, S., MCBRIDE, W., LAU, R., PANG, S., RHOADES, K., DRAKE, T., BELLDEGRUN, A., GLASPY, J., and ECONOMOU, J.S. (1996). In vivo cancer therapy with recombinant interleukin- 2 adenovirus vector. Cancer Gene Ther. 3, 11-17.

XU, M., KUMAR, D., SRINIVAS, S., DETOLLA, L.J., YU, S.F., STASS, S.A., and MIXSON, A.J. (1997). Parental gene therapy with p53 inhibits human breast tumors in vivo through a bystander mechanism without evidence of toxicity. Hum. Gene Ther. 8, 177-185.

YANG, C., CIRIELLI, C., CAPOGROSSI, M.C., and PASSANITI, A. (1995). Adenovinus-mediated wild-type p53 expression induces apoptosis and suppresses tumorigenesis of prostatic tumor cells. Cancer Res. 55, 4210-4213.

Address reprint requests to: Dr. F.L. Graham Department of Biology and Pathology McMaster University 1280 Main Street West Hamilton, Ontario L8S4K1 Canada

Received for publication August 22, 1997; accepted after revision January 7, 1998. 